\title{
The influence of environmental characteristics on the distribution of ciliates (Protozoa, Ciliophora) in an urban stream of southeast Brazil
}

\author{
Dias, RJP. ${ }^{\mathrm{a} *}$, Wieloch, AH. ${ }^{\mathrm{b}}$ and D'Agosto, M. ${ }^{\mathrm{a}}$ \\ aPrograma de Pós-graduação em Comportamento e Biologia Animal, Departamento de Zoologia, \\ Instituto de Ciências Biológicas, Campus Universitário, Universidade Federal de Juiz de Fora - UFJF, \\ CEP 36036-900, Juiz de Fora, MG, Brazil \\ bDepartamento de Zoologia, Instituto de Ciências Biológicas, Universidade Federal de Minas Gerais - UFMG, \\ Av. Antônio Carlos, 6627, Pampulha, CEP 31270-910, Belo Horizonte, MG, Brazil \\ *e-mail: rjuniodias@ hotmail.com \\ Received June 12, 2006 - Accepted June 18, 2007 - Distributed May 31, 2008
}

(With 8 figures)

\begin{abstract}
The aim of this research was to study the ciliated protozoa community at three sampling stations that receive different levels of domestic sewage along the São Pedro Stream in the municipality of Juiz de Fora, Minas Gerais, Brazil, in order to determine the influence of organic pollution on this community and to assess the feasibility of using ciliates as water quality indicators. Four physical-chemical parameters of the water samples were evaluated: dissolved oxygen concentration, electrical conductivity, $\mathrm{pH}$ and temperature. The sediment was obtained manually, using dredges with capacity of $300 \mathrm{~mL}$, at each collection point. Point 1 was located in a rural region that receives a low sewage load, while Points 2 and 3 were located in populated regions receiving high sewage loads. We found 22 ciliate species, of which 18 are included in the saprobic system and are considered bioindicators. These showed beta-mesosaprobic environments at Point 1 and alfa-mesosaprobic to polisaprobic environments at Points 2 and 3. The low levels of dissolved oxygen and the high electrical conductivity values at Points 2 and 3, together with the strong similarity between the ciliate taxocenoses of these points and the weak similarity between Point 1 and the other two, confirm the high sewage loads received at the latter two points. The combination of the biological indicators and physical-chemical analyses therefore proved itself to be an efficient method of evaluating water quality, and has excellent potential to support decisions on the conservation of headwaters and recuperation of degraded environments in lotic systems.
\end{abstract}

Keywords: ciliated protozoa, organic pollution, water quality, watercourses.

\section{Influência das características ambientais sobre distribuição dos ciliados (Protozoa, Ciliophora) em um córrego urbano no sudeste brasileiro}

\begin{abstract}
Resumo
O objetivo deste trabalho foi estudar a comunidade de protozoários ciliados em três estações amostrais, que recebem diferentes níveis de lançamento de esgoto doméstico, ao longo do córrego São Pedro, Juiz de Fora, MG, a fim de se determinar a influência da poluição orgânica sobre a composição e distribuição desta comunidade e avaliar a viabilidade da utilização dos ciliados como indicadores da qualidade da água. Foram mensurados quatro parâmetros físico-químicos da água amostrada: teor de oxigênio dissolvido, condutividade elétrica, $\mathrm{pH}$ e temperatura. Amostras do sedimento foram obtidas manualmente com o auxílio de dragas, com capacidade de $300 \mathrm{~mL}$, em cada ponto de coleta. O ponto 1, localizado em uma região rural, recebe baixa carga de esgoto, enquanto os pontos 2 e 3 , localizados em regiões com ampla ocupação humana, recebem altas cargas de esgoto. Foram registradas 22 espécies de ciliados, sendo que 18 estão incluídas no sistema sapróbio e são consideradas bioindicadoras de ambientes beta-mesossapróbio no ponto $1 \mathrm{e}$ de alfa a polissapróbio nos pontos 2 e 3 . Os baixos valores de oxigênio dissolvido e os altos valores de condutividade elétrica registrados nas estações 2 e 3, juntamente com a similaridade entre a taxocenose de ciliados destas estações e a baixa similaridade entre a estação 1 e as demais, confirmaram as altas cargas de esgoto recebidas nestas estações. A união do método biológico com a análise físico-química mostrou-se, portanto, um eficiente método na avaliação da qualidade da água, e apresenta grande potencial de utilização em tomadas de decisões relativas à conservação de nascentes e recuperação de ambientes degradados em sistemas lóticos.
\end{abstract}

Palavras-chave: águas correntes, poluição orgânica, protozoários ciliados, qualidade da água. 


\section{Introduction}

Studies on pollution effects in freshwater environments were traditionally based on observing the physical and chemical characteristics of the water (Norris and Thoms, 1999). However, these parameters, isolated from the analysis of the biotic community, do not provide enough evidence to completely evaluate water quality. The current trend is to analyze not only changes in the physical-chemical characteristics, but also the responses to these changes by the organisms that live in these environments. Biological data, together with physical and chemical data represent an important tool to evaluate water quality in rivers and streams and have contributed to efforts to control emissions of organic pollutants in urban lotic systems (Suehiro and Tezuca, 1981; Groliére et al., 1990; Sparagano and Grolière, 1991; Madoni, 1993; Fernandez-Leborans and Novillo, 1996; Sola et al., 1996; Madoni and Bassanini, 1999; Madoni, 2005; Madoni and Braghiroli, 2007).

In this context, ciliated protozoa are very important because the disturbances caused by pollution can significantly alter the aquatic food chain, and thus the composition and abundance of these protozoa (Czapik, 1982; Primc, 1988; Primc-Habdija et al., 1998; Madoni and Bassanini, 1999; Madoni and Braghiroli, 2007).

The use of ciliated protozoa as bioindicators has advantages over the use of other organisms. The high sensitivity of these protists to changes in their surroundings, allied with their short generation time, enables them to reveal the response to environmental contamination much more quickly. Besides this, they are widely distributed geographically, being essential components of nearly all environments and can be easily maintained in the laboratory (Sparagano and Grolière, 1991; Piccinni and Gutiérrez, 1995; Fernandez-Leborans and Novillo, 1996).

Their great sensitivity to physical and chemical factors can be explained by the fact that many protozoa have specific demands in relation to the characteristics of the medium in which they live, such as the quantity of dissolved organic matter, temperature, $\mathrm{pH}$, electric conductivity and dissolved oxygen concentration (Noland, 1925; Kudo, 1966; Sleigh, 1988). Among these characteristics, the quantity of organic matter and dissolved oxygen in the water define pollution zones that are associated with particular species of protozoan indicators (Foissner and Berger, 1996). Four main zones of pollution are distinguished: polysaprobity (very heavily polluted), alfa-mesosaprobity (heavily polluted), betamesosaprobity (moderately polluted) and oligosaprobity (clean or very slightly polluted) (Streble and Krauter, 1987; Foissner and Berger, 1996).

In recent years many studies have examined the composition, distribution and dynamics of ciliate communities in lotic systems, as well as their value as water quality indicators (Madoni and Ghetti, 1981; Suehiro and Tezuca, 1981; Wiackowski, 1981; Czapik, 1982; Primc, 1988; Groliére et al., 1990; Sparagano and Grolière,
1991; Madoni, 1983; 1984; 1993; Fernandez-Leborans and Novillo, 1996; Sola et al., 1996; Primc-Habdija et al., 1998; Madoni and Bassanini, 1999; Madoni, 2005; Madoni and Braghiroli, 2007).

The present research studies the community of ciliated protozoa at points with different raw domestic sewage levels along São Pedro Stream (Southeast Brazil) to determine the influence of organic pollution on the composition and distribution of this community and to evaluate the use of ciliates as water quality indicators.

\section{Material and Methods}

\subsection{Study area and sampling stations}

The watershed of São Pedro Stream, located in the southwest part of the urban area of the municipality of Juiz de Fora, Minas Gerais, Brazil (Figure 1), includes São Pedro Dam, which is responsible for 9\% of the city's water supply. The streamlet itself extends for 13,250 $\mathrm{m}$ (watercourse) and 10,750 m (straight line), traversing various districts of the municipality. Its headwaters are located at an altitude of $875 \mathrm{~m}$ above sea level (Latuf, 2004).

The collections were done monthly, always in the morning, at three points (Figure 1) along the stream, to obtain samples with different levels of untreated sewage. Point 1 (23K, 663036, 7590303) is located in a rural region and receives a low sewage load, while Points 2 (23K, 668307, 7591772) and 3 (23K, 668645, 7592804) are located in considerably populated regions, receiving high sewage loads.

At each station, samples were collected monthly from August 2002 to June 2003. Benthic ciliates were collected from the substrate by using dredges with capacity of $300 \mathrm{~mL}$, at each collection point. At each station three samples were collected along the line of the river cross-section and near the border. Glass jars were lowered to the bottom, recovered and capped. The samples were then put in thermal containers to maintain their physical conditions and taken to the laboratory.

\subsection{Physical and chemical parameters}

Monitoring of the physical and chemical properties of the water at the sampling points was done with portable equipment at the collection sites, recording the following parameters: dissolved oxygen concentration, electrical conductivity, $\mathrm{pH}$ and water temperature.

\subsection{Processing the samples and identifying the ciliates}

Of the samples taken to the laboratory, we placed five fractions of approximately $20 \mathrm{~mL}$ in Petri dishes to observe the organisms under a stereoscopic microscope with transmitted light, on the day of collection. The ciliates was sorted from these portions with micropipettes (made in the laboratory) and observed in vivo (Tuffrau, 1959) until eight hours after their collection, under an optical microscope (bright field and phase contrast) in order to make preliminary identifica- 


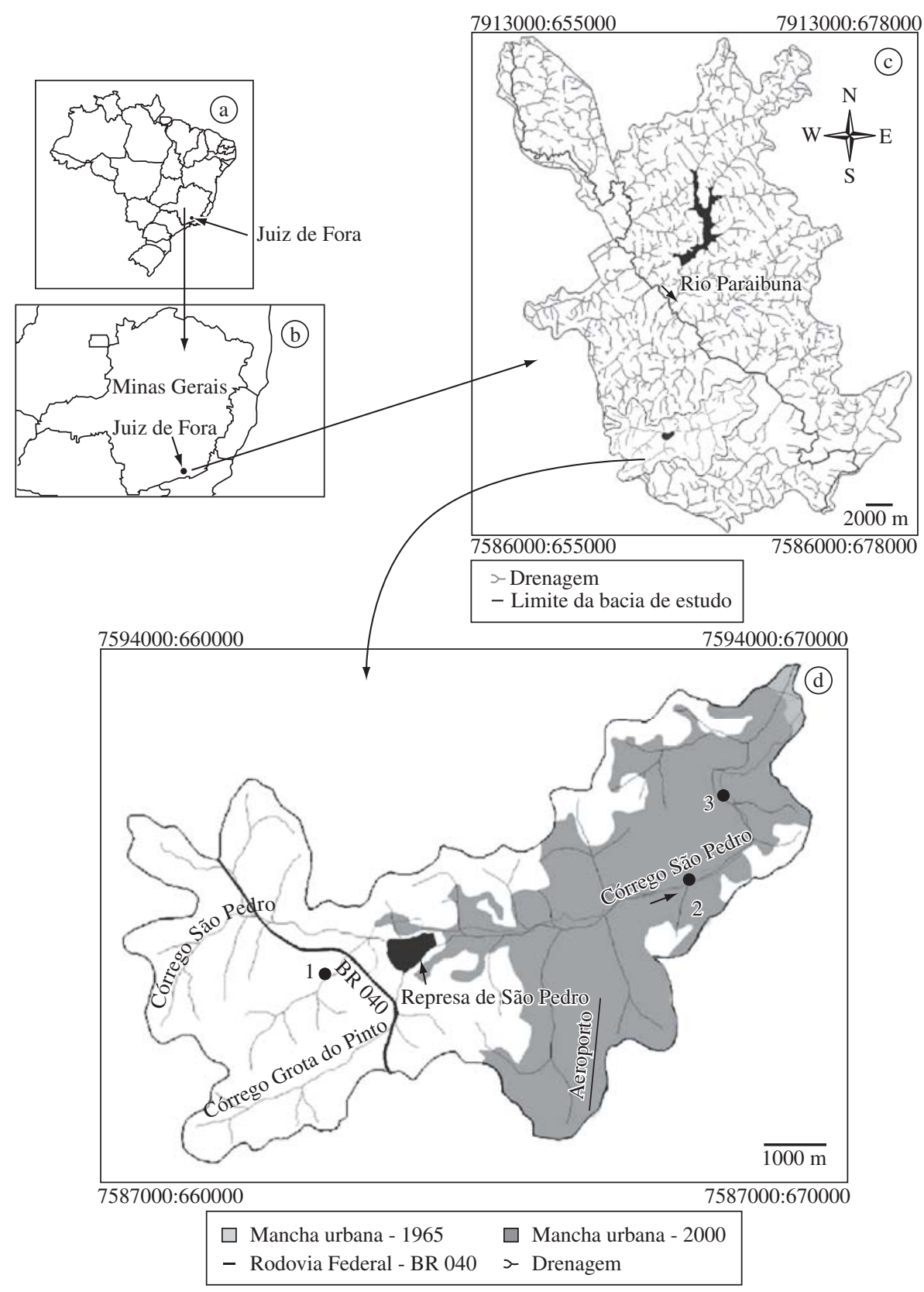

Figure 1. Map of the São Pedro streamlet showing the sampling stations $(\mathrm{P} 1=$ Station $1 ; \mathrm{P} 2=$ Station $2 ; \mathrm{P} 3=$ Station 3$)$ in the urban area of Juiz de Fora, Minas Gerais, Brazil (from Latuf, 2004).

tions. Observation of live ciliates is of great taxonomic importance in classifying genera and species (Foissner and Berger, 1996). Cultures were prepared to carry out further identification techniques, adding crushed rice in fractions of other samples. The rice grains served as a source of carbon for the bacteria present, encouraging excystment of the ciliates. The following silver impregnation techniques were carried out: protargol (Dieckmann, 1995) and "dry" silver (Klein, 1958; Foissner, 1991).

\subsection{Statistical treatment}

The Mann-Whitney nonparametric test was used to verify differences between the mean values of the physical and chemical parameters among the three collection stations.

Cluster analysis, with Euclidian distance and UPGMA, was used to examine the similarity among these parameters at the three collection points, as well as the data showing presence or absence of the ciliate community at the points. To determine the degree of similar- 
ity among the ciliate communities of the three sampling stations, the qualitative similarity indices of Jaccard and Sorensen (Magurran, 1988) was calculated.

\section{Results and Discussion}

\subsection{Physical and chemical analysis}

Dissolved oxygen is one of the most important gases in the dynamics and characterization of aquatic ecosystems (Esteves, 1988; Von Sperling, 1996). The low average oxygen values obtained at Points $2\left(3.02 \mathrm{mg} . \mathrm{L}^{-1}\right)$ and 3 (2.04 mg. $\left.\mathrm{L}^{-1}\right)$, when compared with the high average values at Point 1 (6.49 mg.L $\mathrm{L}^{-1}$ ) (Figure 2), indicate high organic pollution loads at the stations in the urban area (Points 2 and 3). There was a significant difference (Mann-Whitney test, $\mathrm{p}<0.05$ ) between the mean $\mathrm{O}_{2}$ values from Point 1 in relation to Points 2 and 3 , and no significant difference (Mann-Whitney test, $\mathrm{p}<0.05$ ) between the mean $\mathrm{O}_{2}$ values of Points 2 and 3 .

The electrical conductivity of a solution is considered an important variable in characterizing water bodies and detecting sources of pollution (Esteves, 1988). The low conductivity levels at Point 1 and high values at Points 2 and 3 confirm the high sewage loads received at the latter two collection sites (Figure 3). There was a significant difference (Mann-Whitney test, $\mathrm{p}<0.05$ ) between the mean electrical conductivity values from Point $1\left(78.6 \mu{\mathrm{S} . \mathrm{cm}^{-1}}^{-1}\right)$ in relation to the sampling stations $2\left(286.4 \mu{\mathrm{S} . \mathrm{cm}^{-1}}^{-1}\right)$ and $3\left(293.0 \mu \mathrm{Scm}^{-1}\right)$, and no significant difference (Mann-Whitney test, $\mathrm{p}>0.05$ ) between these average values from Points 2 and 3.

The water temperature was nearly the same at all three collection points: $1\left(22.4{ }^{\circ} \mathrm{C}\right), 2\left(22.5{ }^{\circ} \mathrm{C}\right)$ and $3\left(23.2{ }^{\circ} \mathrm{C}\right)$, with no significant difference (MannWhitney test, $\mathrm{p}>0.05$ ) among them (Figure 4).

Point 2 (7.41) and Point 3 (7.46) had lower $\mathrm{pH}$ values than Point 1 (8.11) (Figure 5). In lakes where there is an upper aerobic layer and another anaerobic layer at

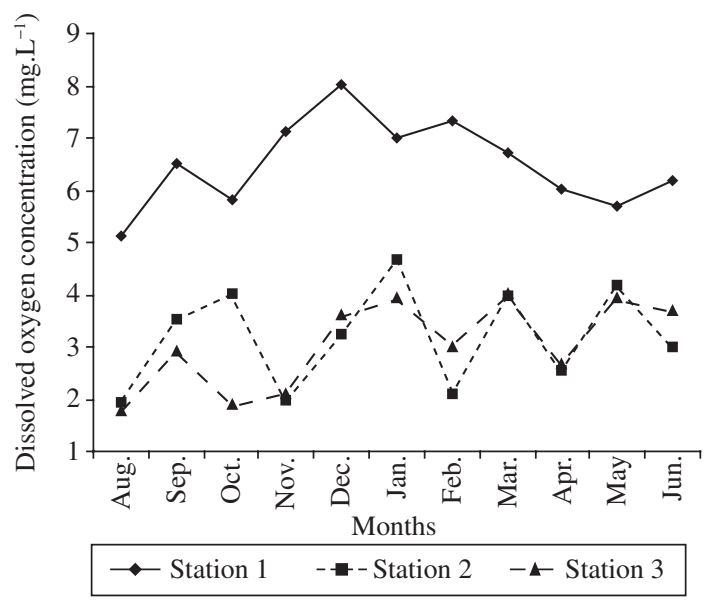

Figure 2. Variation of dissolved oxygen concentration from three points along São Pedro stream, from August 2002 to June 2003.

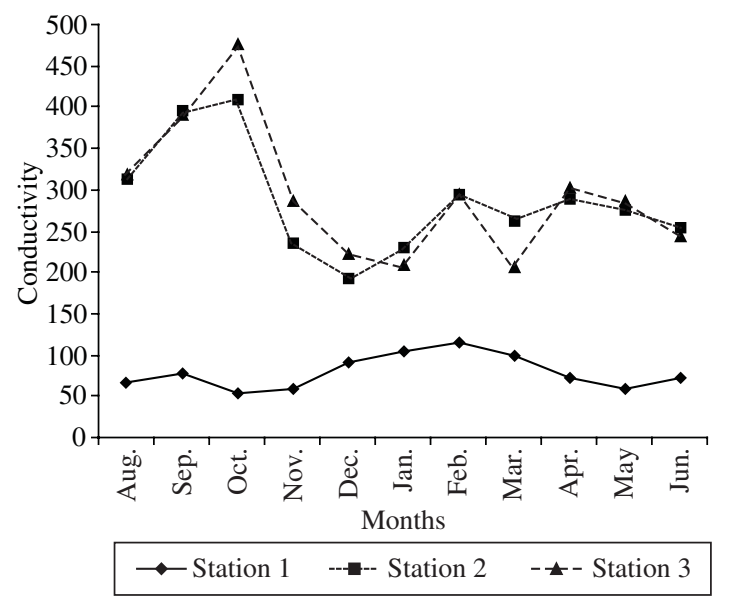

Figure 3. Variation of conductivity from three points along São Pedro stream, from August 2002 to June 2003.

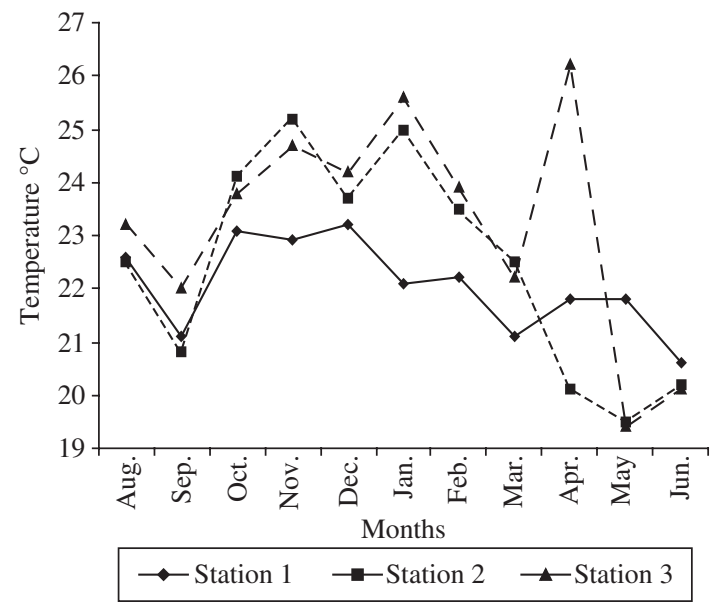

Figure 4. Variation of temperature from three points along São Pedro stream, from August 2002 to June 2003.

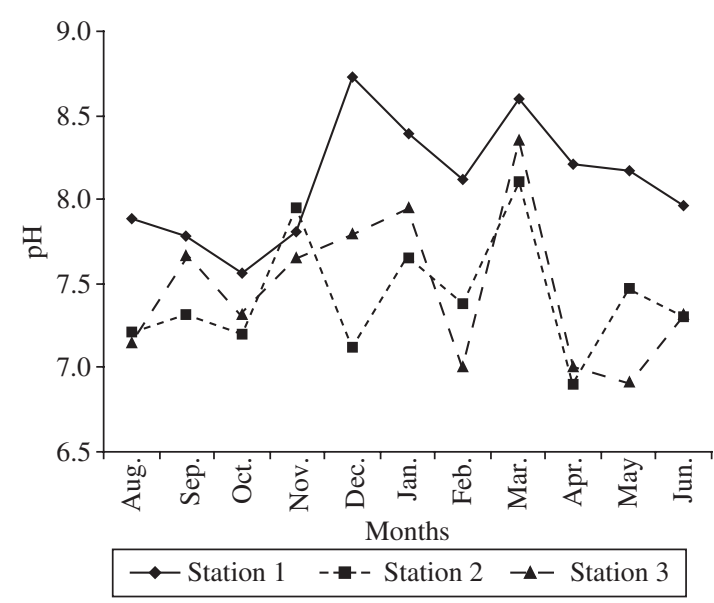

Figure 5. Variation of $\mathrm{pH}$ from three points along São Pedro stream, from August 2002 to June 2003. 
the bottom, anaerobia can cause elevation of the $\mathrm{pH}$ as a consequence of photosynthetic action. It is interesting to note that phenomena like those that keep the $\mathrm{pH}$ slightly base in polluted waters can also be occurring in lotic systems, such as in the São Pedro Stream, in stretches that receive high domestic sewage loads. These effluents flow in constantly, forming a layer of activated mud on the bed. This layer can be washed out during extremely rainy periods, but it accumulates again in short order (Branco, 1986). There was a significant difference (Mann-Whitney test, $\mathrm{p}<0.05$ ) between the mean $\mathrm{pH}$ values for Point 1 in relation to Points 2 and 3 , and no significant difference (Mann-Whitney test, $\mathrm{p}<0.05$ ) between these mean values for Points 2 and 3.

The similarity between collection stations 2 and 3, regarding physical and chemical parameters, is shown in Figure 6.

\subsection{Biological analysis}

Table 1 presents the ciliated protozoa taxa that were identified from São Pedro Stream during the study and the occurrence frequency of each species at the three sample stations along eleven months sampling. A total amount of 22 species of ciliated protozoa belonging to 20 genera were identified. The species Coleps sp., Spirostomum minus Roux, 1901, Frontonia leucas (Ehrenberg, 1833), Urocentrum turbo Ehrenberg, 1838, Stylonychia pustulata Müller, 1786 and Vorticella sp. occurred at all the sampling stations. The species occurring at only one station were: Halteria sp. at Station 1, Podophrya fixa Müller, 1786 at Station 2; and Stentor coeruleus Ehrenberg, 1830, Tokophrya lenarum Stein, 1859 and Blepharisma sinuosum Sawaya, 1940 at Station 3. Of the 22 taxa recorded, 17 occurred at Stations 2 and 3.

The smaller number of species registered at Station 1 (6 species) in comparison with Stations 2 (18 species) and 3 (20 species) (Table 1) can be related to the low abundance of species typical of clear water and headwaters, making them harder to find in samples collected from that station. Foissner (1997), studying the ciliate fauna of four clear water rivers in Germany, attributed the low abundance of ciliates encountered to a possible shortage of nutrients in these environments.

The degree of similarity among the ciliate taxocenoses at the three sampling stations studied is shown

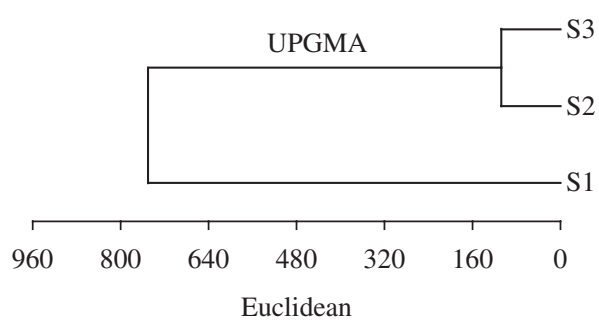

Figure 6. Dendrogram of cluster analysis, showing the similarities among stations (S1, S2 and S3) on the basis of physical and chemical qualities. in Table 2 and Figure 7. As expected, there was a close similarity between Stations 2 and 3 and low similarity between these two and Station 1.

The species Stentor coeruleus and Blepharisma sinuosum were recorded only in the cultures kept in the laboratory (Table 1), because they possibly were encysted in the samples analyzed on the collection day, due to the unfavorable environmental conditions. In the cultures, with favorable food supply, the excystment of these species occurred. However, it was not possible to investigate these species in the ecological study because they had not been registered on the collection day. The excystment mechanism is important because it permits the ciliated protozoan populations to resist predation, unfavorable physical and chemical conditions and food shortages (Taylor, 1983).

The saprobic system for evaluating water quality, and more specifically for assessing organic pollution, developed by Kolkwitz and Marsson $(1908,1909)$ and Kolkwitz (1950), is widely used in biological classification of flowing waters. The original lists of indicator species has been revised and extended by various authors (Sladeček, 1973; Sladeček et al., 1981; Foissner, 1988, Foissner et al., 1995), who have added data on the water quality and revised taxonomic errors (Paiva and Silva-Neto, 2004).

Among the ciliate species found in São Pedro Stream, 18 are included in the sabrobic system and are considered bioindicators: Caenomorpha sp., Lagynus sp., Loxodes striatus (Eugelmann, 1862) Penard, 1917, Metopus sp., Paramecium caudatum Ehrenberg, 1838, Plagiopyla sp. and Spirostomum teres Clapère et Lachmann, 1958 are indicators of polysaprobic environments; Euplotes eurystomus Wrzesmiowski, 1870, Podophrya fixa, Stentor coeruleus and Tokophrya lenarum of alfa-mesosaprobic environments; Coleps sp., Spirostomum minus and Stentor polymorphus Ehrenberg, 1830 of alpha-mesosaprobic to beta-mesosaprobic environments; Frontonia leucas, Urocentrum turbo and Stylonychia pustulata of beta-mesosaprobic environments; and Halteria sp., which indicates oligosaprobic to alpha-mesosaprobic environments (Table 1).

Figure 8 shows the presence of indicator species of alpha-mesosaprobic and polysaprobic environments at Stations 2 and 3 and the occurrence of an indicator species of an oligosaprobic environment only at Station 1. Among the eight species included in the saprobic system that occurred exclusively at Stations 2 and 3 (Table 1), only E. eurystomus is an indicator of an alpha-mesosaprobic environment. The others are indicators of a polysaprobic environment. These saprobity levels correspond to class III and IV waters, with low or no oxygen content, characterizing polytrophic environments, meaning extremely polluted (Streble and Krauter, 1987).

At Station 1, where six ciliate species occurred, three of them indicate a beta-mesosaprobic environment, whereas the other two indicate alfa to beta-mesosaprobic environments (Table 1). Thus, this site has a moderate to 
Table 1. List of ciliate species at three stations (S1, S2, S3), with number of positive samples throughout the 11 collecting months, in which each species was found, saprobity levels (S) and main food source (Mf).

\begin{tabular}{|c|c|c|c|c|c|}
\hline Protist species & S1 & S2 & S3 & $\mathbf{S}^{*}$ & Mf \\
\hline Caenomorpha sp. & - & 5 & 5 & $\mathrm{p}-\mathrm{i}$ & $\mathrm{Ba}, \mathrm{Sb}$ \\
\hline Lagynus sp. & - & 1 & 3 & $\mathrm{p}-\mathrm{i}$ & $\mathrm{O}$ \\
\hline Loxodes striatus (Engelmann, 1862) & - & 3 & 4 & $\mathrm{p}$ & $\mathrm{Al}, \mathrm{Ki}, \mathrm{Cy}$ \\
\hline Metopus sp. & - & 5 & 5 & $\mathrm{p}-\mathrm{i}$ & $\mathrm{Ba}, \mathrm{Al}, \mathrm{Fl}$ \\
\hline Paramecium caudatum Ehrenberg, 1833 & - & 11 & 11 & $\mathrm{p}-\mathrm{a}$ & $\mathrm{Ba}, \mathrm{Al}$ \\
\hline Plagiopyla sp. & - & 4 & 2 & $\mathrm{p}-\mathrm{i}$ & $\mathrm{Ba}, \mathrm{Sb}, \mathrm{Al}, \mathrm{Fl}$ \\
\hline Spirostomum teres Claparède and Lachmann, 1858 & - & 5 & 5 & $\mathrm{p}$ & $\mathrm{Ba}, \mathrm{Sb}, \mathrm{Al}, \mathrm{Ki}$ \\
\hline Euplotes eurystomus Wrzesniowski, 1870 & - & 3 & 4 & a & $\mathrm{O}$ \\
\hline Podophrya fixa (Müller, 1786) & - & 1 & - & a & $\mathrm{R}$ \\
\hline Stentor coeruleus (Pallas, 1766) & - & - & + & a & $\mathrm{O}$ \\
\hline Tokophrya lenarum (Stein, 1859) & - & - & 1 & a & $\mathrm{R}$ \\
\hline Coleps sp. & 3 & 4 & 5 & $a-b$ & - \\
\hline Spirostomum minus Roux, 1901 & 5 & 6 & 6 & $a-b$ & $\mathrm{Ba}$ \\
\hline Stentor polymorphus (Müller, 1773) & - & 3 & 1 & $a-b$ & $\mathrm{Ba}, \mathrm{Al}, \mathrm{Ki}$ \\
\hline Frontonia leucas Ehrenberg, 1833 & 8 & 5 & 5 & $\mathrm{~b}$ & $\mathrm{O}$ \\
\hline Urocentrum turbo Müller, 1786 & 4 & 7 & 9 & $\mathrm{~b}$ & $\mathrm{Ba}, \mathrm{Ki}$ \\
\hline Stylonychia pustutala (Müller, 1786) & 2 & 7 & 7 & $\mathrm{~b}$ & $\mathrm{O}$ \\
\hline Halteria sp. & 2 & - & - & o-a & $\mathrm{Al}$ \\
\hline Blepharisma sinuosum Sawaya, 1940 & - & - & + & - & - \\
\hline Epistylis sp. & - & 3 & 1 & - & - \\
\hline Prorodon sp. & - & 2 & 3 & - & - \\
\hline Vorticella sp. & 1 & 5 & 9 & - & - \\
\hline
\end{tabular}

$\mathrm{p}=$ polisaprobity $; \mathrm{i}=$ isosaprobity; $\mathrm{a}=$ alfa-mesosaprobity; $\mathrm{b}=$ beta-mesosaprobity; $\mathrm{o}=$ oligosaprobity; $\mathrm{Al}=$ algae; $\mathrm{Ba}=$ bacteria $; \mathrm{Cy}=$ cyanobacteria $; \mathrm{Fl}=$ heterotrophic flagellates; $\mathrm{Ki}=$ diatoms; $\mathrm{O}=$ omnivorous; $\mathrm{R}=$ predator; $\mathrm{Sb}=$ sulphur bacteria. $+=$ species recorded only in the cultures kept in the laboratory. *Foissner and Berger (1996).

Table 2. Qualitative similarity indices of Jaccard and Sorensen between the station pairs 1 and 2 (S1-S2), 1 and 3 (S1-S3) and 2 and 3 (S2-S3).

\begin{tabular}{ccc}
\hline \multicolumn{3}{c}{ Qualitative similarity index } \\
\hline Stations & Jaccard & Sorensen \\
\hline S1-S2 & 0.32 & 0.48 \\
S1-S3 & 0.29 & 0.44 \\
S2-S3 & 0.81 & 0.89 \\
\hline
\end{tabular}

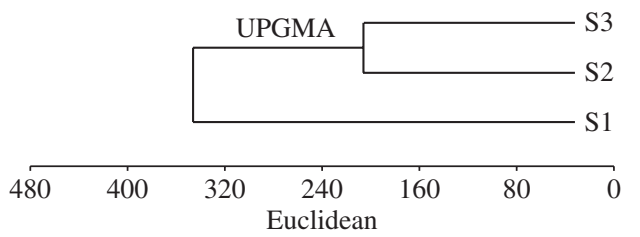

Figure 7. Dendrogram of cluster analysis, showing the similarities among stations (S1, S2 and S3) on the basis of ciliate taxocenoses.

critical grade of pollution. Among the species that occurred at all the collection stations (Table 1), S. minus, F. leucas and $U$. turbo have been reported along rivers with different saprobic levels (Wiackowski, 1981;

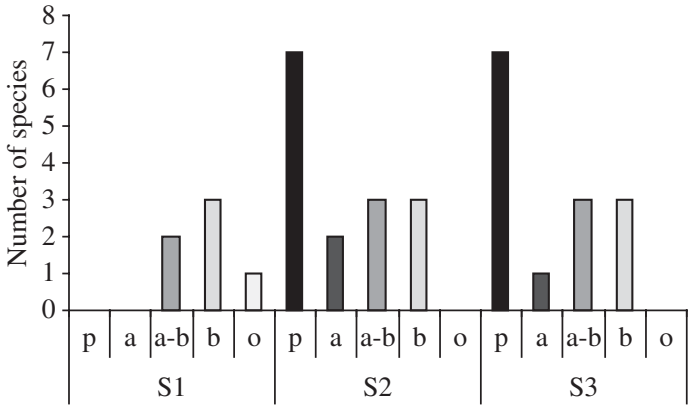

Figure 8. The number of species indicators of polisaprobity (p), alfa-mesosaprobity (a), alfa to beta-mesosaprobity (a-b), betamesosaprobity (b) and oligosaprobity (o) environments at the three stations (S1, S2 and S3).

Czapik, 1982; Madoni and Ghetti, 1982; Sparagano and Grolière, 1991; Sola et al., 1996; Madoni and Bassanini, 1999), which shows the ample ecological valence that is characteristic of this species.

Several authors, studying rivers in France (Sparagano and Grolière, 1991), Spain (Sola et al., 1996), Italy (Madoni and Ghetti, 1981; Madoni, 1993; Madoni and 
Bassanini, 1999; Madoni, 2005; Madoni and Braghiroli, 2007) and Poland (Wiackowski, 1981), have demonstrated an increased proportion of polysaprobic and alphamesosaprobic species and a decrease in beta-metosaprobic and oligosaprobic species with increasing pollution loads caused by anthropic impacts. Madoni (1993) demonstrated the efficiency of using ciliate protists as water quality indicators in the Parma River, comparing data collected in 1978, when the system received untreated sewage, and in 1989, after a treatment station was operating. The marked change in the ciliate community was accompanied by an increase in organic load, which caused the disappearance of some typical species and dampened the diversifying effects of other environmental factors, producing comparatively similar community structures in that whole zone.

The species Coleps sp., Epistylis sp. and Vorticella sp. have not been classified as to saprobity because they have only been identified at the genus level. On the lists of indicators contained in Foissner (1988) and Foissner and Berger (1996), the genera Coleps Nitzsch, 1817, Epistylis Ehrenberg, 1830 and Vorticella Linnaeus, 1767 indicate environments that vary from oligosaprobic to alpha-mesosaprobic. The presence of Epistylis sp. only at Stations 2 and 3 and the greater frequency of Vorticella sp. at these stations as well (Table 1), corroborate that peritrichous ciliates are strongly related to organic pollution (Antipa, 1967; Burbanck and Spoon, 1967; Henebry and Ridgeway, 1979).

The indicator species of polysaprobic environments recorded at Stations 2 and 3, located in the urban area of São Pedro Stream, have been reported by various authors in eutropic lakes (Finlay, 1981, 1982; Laybourn-Parry et al., 1990), at sewage treatment stations (Salvadó et al., 1995) and in polluted rivers and streams (Madoni and Ghetti, 1981; Suehiro and Tezuca, 1981; Wiackowski, 1981; Czapik, 1982; Sola et al., 1996; Madoni and Bassanini, 1999; Madoni, 2005; Madoni and Braghiroli, 2007).

In his guide to freshwater protozoa, Patterson (1996) classified the species of the genera Metopus (Claparède et Lachman, 1850), Caenomorpha Perty, 1852, Plagiopyla Stein, 1860, Spirostomum Ehrenberg, 1833 and the species L. striatus as anoxic benthonic ciliates. Foissner and Berger (1996) included Caenomorpha spp., Metopus spp., Plagiopyla nassuta, Loxodes spp. and Lagynus elegans in a community called "Metopetum", composed mainly of strictly anaerobic organisms, which do not have mitochondria and present sulphurous bacteria as symbionts, being "infallible" indicators (Czapik, 1982) of the presence of sulphurated hydrogen in the water. Heterotropic sulphurous bacteria occur principally at the surface of sediment, where the reducing conditions are more favorable, and appear in great densities in highly polluted environments (Esteves, 1988).

The availability of food is an important biotic factor that controls the distribution of ciliated protozoan popu- lations in the various ecosystems (Noland, 1925; Sleigh, 1988). Several studies have shown the effect of pollution on the trophic relationships of the community of ciliated protozoa in flowing waters (Wiackowski, 1981; Czapik, 1982; Primc, 1988; Primc-Habdija et al., 1998; Madoni and Bassanini, 1999; Madoni, 2005; Madoni and Braghiroli, 2007).

In oligosaprobic waters, ciliates mainly feed on algae, while only a few feed on bacteria and cyanobacteria. The trophic relationships are significantly altered when the level of saprobity increases. These changes start with a decrease in the number of algivorous ciliates and an increase in the number of bacterivorous species (Wiackowski, 1981; Czapik, 1982; Madoni and Bassanini, 1999; Madoni, 2005). Organic pollutants cause an increase in phosphates and other nutrients, altering the structure of bacteria communities, inducing changes in the ciliate fauna, which depend directly on these bacteria for food (Primc, 1988).

Among the species that occurred at all the collection stations (Table 1), only S. minus is exclusively bacterivorous. F. leucas and S. pustulata are omnivorous and $U$. turbo can feed on both bacteria and diatoms. The species of the genus Coleps are mostly omnivorous and some species of the genus Vorticella can feed on algae and bacteria (Foissner and Berger, 1996). The omnivorous feeding habits of some ciliate species enable them to occur both in headwaters and polluted stretches of rivers and streams, as demonstrated in various studies (Czapik, 1982, Sparagano and Grolière, 1991, Packroff and Zwick 1996, Sola et al. 1996, Madoni and Bassanini 1999). In the present work, Halteria sp., which occurred only at Station 1, is algivorous, indicating an environment with little impact. This corroborates the data obtained by Czapik (1982), who recorded species with this feeding habit at well preserved spots along a river polluted by domestic sewage.

Among the ten species recorded exclusively at Stations 2 and 3 (Table 1), 70\% are indicators of polysaprobic environments, and the majority preferentially bacterivorous. Among the bacterivorous ciliates, the most specialized are those that feed on sulfurous bacteria, indicating highly degraded environments (Czapik, 1982). The species Caenomorpha sp., Lagynus sp., Metopus sp. and Plagiopyla sp. registered in the present paper are examples of this group of ciliates.

The study of the physical and chemical characteristics of São Pedro Stream, such as low levels of dissolved oxygen and high electrical conductivity values recorded at Stations 2 and 3 (Figures 2 and 3), as well as the high similarity among the ciliate taxocenoses at these stations and the low similarity between Station 1 and the other two (Figure 7), confirm the high sewage loads at these stations, along with the high sensitivity of the ciliate populations to changes in organic pollution and the saprobic condition in running waters.

The combination of the biological method (ciliate community) with the traditional method (physical and 
chemical data), therefore, is an efficient way to evaluate water quality and has great potential for use in reaching decisions on the preservation and recuperation of degraded lotic systems.

Acknowledgements - We acknowledge the help of Dr. Roberto da Gama Alves (Zoology Department, ICB, UFJF) with the statistical and ecological analysis and Márcia Regina Silva Alves for assisting with the impregnation of the specimens. We are very grateful to Dr. Inácio da Silva-Neto (Zoology Department, CCS, UFRJ) and all of the laboratory staff for their incentive in the study of the ciliates. Thanks are also due to Dr. Érik Daemon (Zoology Department, ICB, UFJF) for reviewing this manuscript. This research was supported by CNPq.

\section{References}

ANTIPA, GA., 1977. Use of commensal protozoa as biological indicators of water quality and pollution. Trans. Am. Microsc. Soc., vol. 96, p. 482-489.

BRANCO, SG., 1986. Hidrobiologia aplicada à engenharia sanitária. São Paulo: Cetesb. 616 p.

BURBANCK, WD. and SPOON, DM., 1967. The use of sessile ciliates collected in plastic Petri dishes for rapid assessment of water pollution. J. Protozool., vol. 14, p. 739-744.

CZAPIK, A., 1982. The effect of waste water on ciliate communities in the Biata Przemsza River. Acta Hydrobiol., vol. 24 , no. 1 , p. 29-37.

DIECKMANN, J., 1995. An improved protargol impregnation for ciliates yielding reproducile results. Europ. J. Protistol., vol. 31, p. 372-382.

ESTEVES, FA., 1988. Fundamentos de limnologia. Rio de Janeiro: Interciência. 575 p.

FENCHEL, T., 1987. Ecology of Protozoa. The biology of free-living phagotrophic protists. Berlin and Tokyo: Springer. $197 \mathrm{p}$.

FERNANDEZ-LEBORANS, G. and NOVILLO, A., 1996. Protozoan communities and contamination of several fluvial systems. Water Environ. Res., vol. 68, no. 3, p. 311-319.

FINLAY, BJ., 1981. Oxygen availaity and seasonal migrations of ciliated protozoa in a freshwater lake. J. Gen. Microbiol., vol. 123, p. 173-178.

FINLAY, BJ., 1982. Effects of seasonal anoxia on the community of benthic ciliated protozoa in a productive lake. Arch. Hydrobiol., vol. 125, p. 215-222.

FOISSSNER, W., 1988. Taxonomic and nomenclatural revision of Sládeček's list of ciliates (Protozoa: Ciliophora) as indicators of water quality. Hydrobiologia, vol. 166, p. 1-64.

FOISSNER, W., 1991. Basic ligth and scanning electron microscopic methods for taxonomic studies of ciliated protozoa. Europ. J. Protistol., vol. 27, p. 313-330.

FOISSNER, W., 1997. Faunistic and taxonomic studies on ciliates (Protozoa, Ciliophora) from clean rivers in Bavaria (Germany), with description of a new species and ecological notes. Limonologica, vol. 27, no. 2, p. 179-238

FOISSNER, W., BERGER, H., BLATTERER, H. and KOHMANN, F., 1995. Taxonomische und ökologische revision der ciliaten des saprobiensystems - Band IV: Gymnostomates,
Loxodes. Munich: Informationsberichte des Bayer Landesamtes für Wasserwirtschaft. $540 \mathrm{p}$.

FOISSNER, W. and BERGER., H. 1996. A user-friendly guide to ciliates (Protozoa, Ciliophora) commonly used by hydrobiologists as bioindicators in rivers, lakes, and waste waters, with notes on their ecology. Freshw. Biol., vol. 35, p. $375-498$

GROLIÈRE, CA., CHAKLI, R., SPARAGANO, O. and PEPIN, D. 1990. Application de la colonisation d'un substrat artificiel par les ciliés à l'étude de la qualité des eaux d'une riviére. Europ. J. Protistol., vol. 25, p. 381-390.

HENEBRY, MS. and RIDGEWAY, BT., 1979. Epizoic ciliated protozoa of planktonic copepods and cladocerans and their possible use as indicators of organic pollution. Trans. Am. Microsc. Soc., vol. 98, no. 4, p. 495-508.

KLEIN, BN., 1958. The "dry" silver method and its proper and use. J. Protozool., vol. 5, no. 2, p. 99-103.

KOLKWITZ, R. and MARSSON, K., 1908. Ökologie der pfanzlichen Saprobien. Berichte der Deutschen Botanischen Gesellschaft, vol. 26, p. 505-519.

KOLKWITZ, R. and MARSSON, K., 1909. Ökologie der tierischen Saprobien. Int. Revue ges. Hydrobiol. Hydrogr., vol. 2, p. 126-152.

KOLKWITZ, R., 1950. Okologie der Saprobien. SchReihe Ver Wass-Boden-u-Lufthyg., vol. 4, p. 1-64.

KUDO, RR., 1966. Protozoology. Illinois: Charles C. Thomas. $786 \mathrm{p}$.

LATUF, M., 2004. Diagnóstico das águas superficiais do córrego São Pedro, Juiz de Fora/MG. Geografia, vol. 13, no. 1, p. 18-55. Available from: http://www.geo.uel.br/revista. [Visited March $12,2006]$

LAYOURN-PARRY, J., 1990. The hypolimnetic protozoan plankton of a eutrophic lake. Hydrobiologia, vol. 203, p. 111-119.

MADONI, P. and GHETTI, PF., 1981. Ciliated Protozoa and water quality in the Torrente Stirone (Northern Italy). Acta Hydrobiol., vol. 23, no. 2, p. 143-154.

MADONI, P., 1983. Relationship between ciliated protozoa and ecological zones in some water courses of the River Po Basin. Int. J. Ecol. Environ. Science, vol. 9, p. 87-98.

-, 1984. Ecological characterization of different types of watercourses by the multivariate analysis of ciliated protozoa populations. Acta Hydrobiol., vol. 100, no. 2, p. 171-188.

,- 1993. Ciliated protozoa and water quality in the Parma River (Northern Italy): long-term changes in the community structure. Hydrobiologia, vol. 264, p. 129-135.

-, 2005. Ciliated protozoan communities and saprobic evaluation of water quality in the hilly zone of some tributaries of the Po River (northern Italy). Hydrobiologia, vol. 541, p. 55-69.

MADONI, P. and BASSANINI, N., 1999. Longitudinal changes in the ciliated protozoa communities along a fluvial system polluted by organic matter. Europ. J. Protistol., vol. 35, p. 391-402.

MADONI, P. and BRAGHIROLI, S., 2007. Changes in the ciliate assemblage along a fluvial system related to physical, chemical and geomorphological characteristics. Europ. J. Protistol. vol. 43, no. 2, p. 67-75. 
MAGURRAN, AE., 1988. Ecological diversity and its measurement. Princeton, New Jersey: Princeton University Press. $179 \mathrm{p}$.

NOLAND, LE., 1925. Factors influencing the distribution of fresh water ciliates. Ecology, vol. 6, p. 437-452

NORRIS, R. and THOMS, M., 1999. What is river health? Freswater Biology, vol. 41, p. 197-209.

PACKROFF, G. and ZWICK, P., 1996. The ciliate fauna of an unpolluted foothill stream, the Breitenbach, 1: qualitative aspects. Limnologica, vol. 26, no. 3, p. 255-262.

PAIVA, TS. and SILVA-NETO. ID., 2004. Ciliate protists from Cabiúnas lagoon (Restinga de Jurubatiba, Macaé, Rio de Janeiro) with emphasis on water quality indicator species and description of Oxytricha marcili sp. n. Braz. J. Biol. = Rev. Bras. Biol., vol. 64, no. 3A, p. 465-478.

PATTERSON, DJ., 1996. Free-living freshwater protozoa: a colour guide. USA: John Wiley \& Sons. p. 181-191.

PICCINNI, E. and J. GUTIÉRREZ., 1995. Protists as bioindicators in the environment. Protistol. Actualities, vol. 1, p. 173-184.

PRIMC, B., 1988. Trophic relationships of ciliated Protozoa developed under different saprobic conditions in the periphyton of the Sava River. Period. Biol., vol. 90, no. 3, p. 349-353.

PRIMC-HABDIJA, B., HABDIJA, I. and RADANOVIC, I., 1998. Seasonal changes in trophic structure of periphytic ciliates in relation to discharge regime. Verh. Inter. Ver. Limnologie, vol. 26, p. 1116-1119.

SALVADÓ, H., GRACIA, M. and AMIGÓ, J., 1995. Capability of ciliated protozoa as indicators of effluent quality in activated sludge plants. Water Res., vol. 29, no. 4, p. 1041-1050.

SLÀDEČEK, V., 1973. System of water quality from the biological point of view. Arch. Hydrobiol. Beih. Ergebn. Limnol., vol. 7, no. I-IV, p. 1-218.
SLÀDEČEK, V., ZELINKA, M., ROTSCHEIN, J., and MORACOVÁ, V., 1981. Biologický rozbor povrchové vody. Komentár k CSN 830532- eásti 6: Stanovi saprobniho indexu. Vydalo Vydavatelstvi Üradu pro normalizaci a mereni, Phara, $186 \mathrm{p}$.

SLEIGH, M., 1988. Protozoa and other Protists. New York: Chapman and Hall. 399 p.

SOLA, A., LONGÁS, JF., SERRANO, S. and ALMUDENA, A. 1996. Influence of environmental characteristics on the distribution of ciliates in the River Henares (Central Spain). Hydrobiologia, vol. 324, p. 237-252.

SPARAGANO, O. and GROLILÈRE, CA., 1991. Evaluation de la qualité des eaux d'une rivière avec les protozoaires ciliés comme bioindicteurs de pollution. Comparaison avec la physico-chimie. Hydroecol. Applique, vol. 1, p. 43-62.

STREBLE, H. and KRAUTER., D., 1985. Atlas de los Microorganismos de agua dulce. Barcelona: Omega. 337 p.

SUEHIRO, S. and TEZUCA, Y., 1981. Seasonal change in ciliate populations in the bottom sediment of a polluted river. Jap. J. Limnol., vol. 42, no. 1, p. 1-7.

TAYLOR, WD. 1983. A comparative study of the sessile, filter-feeding ciliates of several small streams. Hydrobiologia, vol. 98 , p. 125-133.

TUFFRAU, M., 1959. Un dispositif simple pour l'obsevation durable in vivo des microorganismes. Hydrobiologia, vol. 18, no. 4 , p. 316-318.

VON-SPERLING, M. 1996. Introdução à qualidade das águas e ao tratamento das águas e ao tratamento de esgotos. Belo Horizonte: Universidade Federal de Minas Gerais. vol. 1. $243 \mathrm{p}$.

WIACKOWSKI, K., 1981. Analysis of Ciliata from polluted sector of the River Drwinka on the basis of binary data. Acta Hydrobiol., vol. 23, no. 4, p. 319-329. 